\title{
Particle films: chabazitic zeolites with added microorganisms in the protection and growth of tomato plants (Lycopersicon esculentum L.)
}

\author{
Domenico Prisa* \\ CREA Research Centre for Vegetable and Ornamental Crops, Council for Agricultural Research and Economics, Via dei \\ Fiori 8, 51012 Pescia, PT, Italy
}

Publication history: Received on 10 July 2020; revised on 31 July 2020; accepted on 03 August 2020

Article DOI: https://doi.org/10.30574/gscarr.2020.4.2.0059

\begin{abstract}
In this experiment, given the excellent premises for the use of zeolites in agriculture, the biostimulation and protection capacity of a new chabazite zeolite enriched with microorganisms on tomato plants was evaluated, in order to introduce sustainable innovations on the market that can facilitate the reduction of plant protection products and synthetic fertilizers. The experimentation was divided into two parallel trials, one concerning the growth and biostimulation of tomato plants by mixing appropriate amounts of zeolite enriched with microorganisms (diameter of zeolite 3-6 mm) to the growing medium. The second experiment, instead, concerned the use of micronized chabazite zeolites (D $10 \mu \mathrm{m})$ enriched with microorganisms in the protection from pathogenic fungi (Phytophthora infestans, Leivellula taurica). The test showed a significant improvement in agronomic parameters analysed in tomato plants treated with granular chabazite (3-6 mm) enriched with microorganisms and an improvement in protection against Phytophthora infestans and Leivellula taurica with the use of micronized zeolite also enriched with microorganisms. Zeolites and more specifically chabazite once added into the growing medium can improve the absorption of water and fertilisers and also increase the quality of cultivated plants. The presence of beneficial microorganisms added to chabazite, further improves these aspects and provides the plant with greater protection from biotic and abiotic stress.
\end{abstract}

Keywords: Sustainable applications; Biostimulant; Soil amendments; Mineral particle barrier; Inert pesticide

\section{Introduction}

Zeolites are defined as open-structure aluminosilicates because of their particular crystalline structure, where the molecular size channels passing through the crystalline lattice give a high degree of porosity. Depending on their charge and size, cations can be retained in the pore structure or replaced by other competing ions depending on the complex interactions between the aluminosilicate structure, the ions retained within the pore structure and the ionic properties of the external solution. Zeolites are one of the most common minerals that occur in sedimentary rocks. Their commercial production and use for agriculture did not begin until the 1960s in Japan. Initially zeolites were used for many years to control the moisture content and increase the $\mathrm{pH}$ of acid volcanic soils [1]. Pores and cavities are key features of zeolite materials. The interconnected pores and cavities are occupied by cations and water molecules. The cation exchange of zeolites proceeds by cation diffusion, for example, $\mathrm{Ca}^{2+}, \mathrm{Na}^{+}$cations, which are found in the cavities and channels of zeolites, can be replaced by $\mathrm{K}^{+}, \mathrm{Mg}^{2+}, \mathrm{Fe}^{2+}$. Water in the cavities of the zeolite can be lost by heating without changing the volume of the mineral. Dehydrated zeolite can again absorb the water [2]. About 50 natural zeolite mineral species are known and more than 150 species have been synthesized. The best known are: clinoptilolite, heulandite, natrolite, phillipsite, laumontitis, mordenite, chabazite, stilbite, harmotome, ferrierite, analcime, erionite. There are about 1000 main deposits of zeolites (with stocks over 105 tons) in more than 40 countries worldwide. Clinoptilolite, mordenite, chabazite have an industrial value; analcime, phillipsite and others are also promising [3]. Zeolite deposits are known in Iceland, New Zealand, USA, Japan, Russia (Kamchatka), Caucasus. World reserves of

\footnotetext{
* Corresponding author: Prisa Domenico
} 
zeolite raw materials amount to several tens of billions of tons. The main reserves (10-20 billion tonnes) - in the USA, Japan, CIS countries. In Italy and the Balkans there are from 1 to 10 billion tons of zeolites in each country. When fertilizers are introduced into the soil quickly, a significant part of them can be washed away, leading to contamination of water resources and also reducing the yield of the products [4].

Zeolites are widely used in situations where the efficiency of agriculture is to be improved. As they affect the soil structure, in particular, by reducing soil density and increasing porosity, they increase water permeability. The exceptional chemical and physical properties of natural zeolites make them suitable for use when it comes to improving the efficiency of nitrogen use in agriculture [5,6,7].

The use of plant protection products for pathogen control, are widely used in the production of vegetable, fruit and ornamental crops. Since the 1920s, various research has been carried out on mineral particles to identify those that had insecticidal properties and to determine the mechanisms of action. The data showed that the efficacy against pathogens increased when the particle size was ideally 1-2 $\mu \mathrm{m}$ for better adherence to the insect cuticle. This resulted in partial removal of the insect's outer cuticle through abrasion by non-absorbent hard particles or structural destruction of the epicuticle by absorption of epicuticular lipids to the sorptive particles. Both mechanisms induced a rapid loss of water from the body of the insect and caused death by drying $[8,9]$.

The use of micronized chabazite zeolites has led to increased protection from insects and fungi on fruit, vegetable and ornamental species, probably due to different mechanisms:

(a) the rough structure of chabazite zeolitite causes problems of adherence on leaves and fruits by pathogenic insects; (b) the ability of chabazite zeolite to absorb moisture and water veils determines: (c) the reflective capacity of chabazite zeolite which disturbs the flight of insects; (d) a reduction in the ethylene produced by ripening fruit which normally attracts pathogenic insects, absorbed by the chabazite zeolite sprayed on plants [10].

In this experiment, given the excellent premises for the use of zeolites in agriculture, the biostimulation and protection capacity of a new chabazite zeolite enriched with microorganisms on tomato plants was evaluated, in order to introduce sustainable innovations on the market that can facilitate the reduction of plant protection products and synthetic fertilizers.
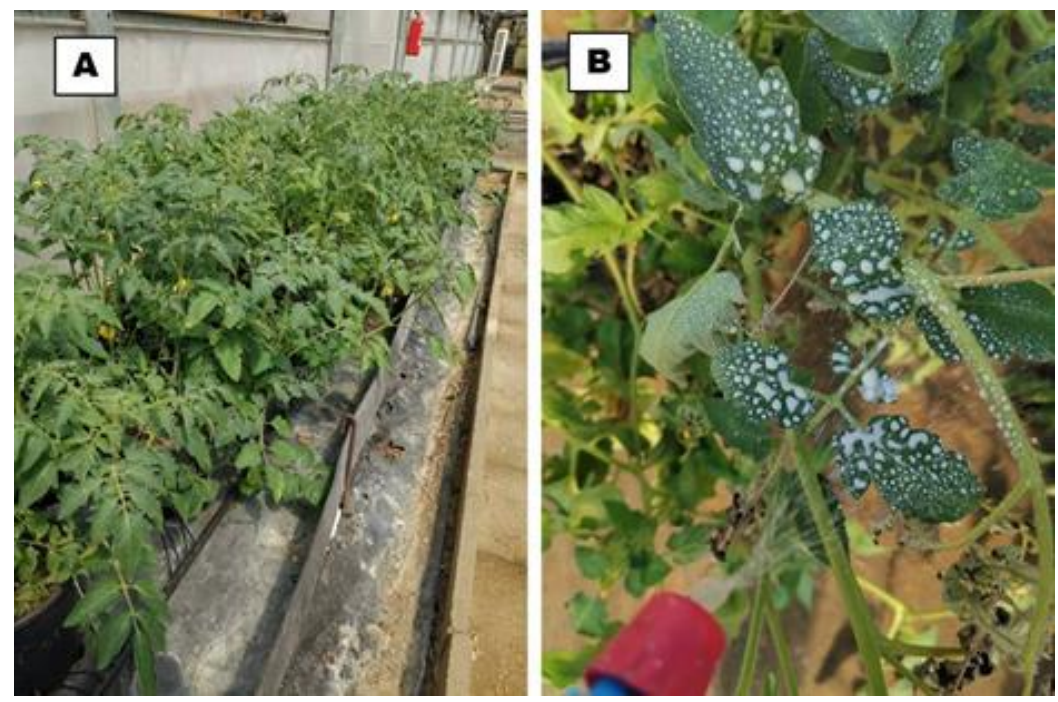

Figure 1 Particular of tomato plants in cultivation (A) and treatment with zeolite sprayed on leaves (B)

\section{Material and methods}

\subsection{Greenhouse experiment and growing conditions}

The experiments, started in January 2020, were conducted in the greenhouses of CREA-OF in Pescia (Pt), Tuscany, Italy $\left(43^{\circ} 54^{\prime} \mathrm{N} 10^{\circ} 41^{\prime} \mathrm{E}\right)$ on Lycopersicon esculentum cv "Siccagno". 
The plants were placed in $\varnothing 24 \mathrm{~cm}$ pots; 30 plants per thesis, divided into 3 replicas of 10 plants each. All plants were fertilized with a controlled release fertilizer ( $3 \mathrm{~kg} \mathrm{~m}^{-3}$ Osmocote Pro®, 6 months with $\left.190 \mathrm{~g} / \mathrm{kg} \mathrm{N}, 39 \mathrm{~g} / \mathrm{kg} \mathrm{P,} 83 \mathrm{~g} / \mathrm{kg} \mathrm{K}\right)$ mixed with the growing medium before transplanting. The experimentation was divided into two parallel trials, one concerning the growth and biostimulation of tomato plants by mixing appropriate amounts of zeolite enriched with microorganisms (diameter of zeolite 3-6 mm) to the growing medium. The second experiment, instead, concerned the use of micronized chabazite zeolites (D $10 \mu \mathrm{m}$ ) enriched with microorganisms in the protection from pathogenic fungi (Phytophthora infestans, Leivellula taurica).

The experimental groups of the Lycopersicon esculentum plant biostimulation test (1) were:

- Group without chabazite zeolites enriched with microorganisms (CT) (peat 70\% + pumice 30\%), irrigated with water and substrate previously fertilized;

- Group with chabazite zeolites (ZE) (peat 70\% + pumice 10\% + chabazite 3-6 mm 20\%), irrigated with water and substrate previously fertilized.

- Group with chabazite zeolites enriched with microorganisms (ZEOB) (peat 70\% + pumice 10\% + chabazite 3$6 \mathrm{~mm} \mathrm{20 \% )} \mathrm{(Patented} \mathrm{formula} \mathrm{rif.28106IT/MB/BF),} \mathrm{irrigated} \mathrm{with} \mathrm{water} \mathrm{and} \mathrm{substrate} \mathrm{previously} \mathrm{fertilized.}$

The experimental groups of the Lycopersicon esculentum plant protection test (2) were:

- $\quad$ Group with commercial substrate (CL) (peat 70\% + pumice 30\%), irrigated with water and substrate previously fertilized; treatments for the control of Phytophthora infestans: Cupravit@ $35 \mathrm{wg}, 2 \%, 6$ treatments; treatments for the control of Leivellula taurica: Flint max ${ }^{2}, 0,2 \%, 2$ treatments;

- Group with commercial substrate (ZEOP) (peat 70\% + pumice 30\%), irrigated with water and substrate previously fertilized; treatments for the control of Phytophthora infestans and Leivellula taurica with chabazite zeolites enriched with microorganisms (Patented formula rif.28106IT/MB/BF): chabazite 2\%, 7 treatments.

All chabazite products were supplied by Balco Greenline of Sassuolo (M0). The chabazitic- zeolites had the following characteristics: 1) qualitative-quantitative mineralogical analysis (\% by weight with standard deviations in brackets) carried out by X-ray powder diffractogram according to the RIETVELD-RIR methodology [11]: chabazite 66.2 (1.0); phillipsite 2.4 (0.5); mica 5.6 (0.6); K-feldspar 10.3 (0.8); pyroxen 2.2 (0.5); volcanic glass 13.3 (1.5); 2) Total zeolithic content (\%): 68.6 (1.3), of which 66.2 due to chabazite and 2.4 from phillipsite. Cation exchange capacity (in meq/g with standard deviation in brackets) determined using the methodology described in Gualtieri et al. (1999) [12]: 2.15 (0.15) of which 1.42 due to $\mathrm{Ca}, 0.04$ to $\mathrm{Mg}, 0.05$ to $\mathrm{Na}$ and 0.64 to $\mathrm{K}$. The chabazite with added PGPR had a microbial count of $4.2 \times 106 \mathrm{ufc} / \mathrm{g}$ of zeolites. The $\mathrm{pH}$ of the zeolite was 6.9.

The plants were watered 2 times a day and grown for 7 months. The plants were irrigated with drip irrigation. The irrigation was activated by a timer whose program was adjusted weekly according to climatic conditions and the fraction of leaching. On June 26, 2020, plant height (measured at 70 days after transplanting), plant nodes (measured at 70 days after transplanting), leaf area index, total dry biomass, leaf chlorophyll (SPAD), fruit fresh weight and total fruit number have been evaluated

\subsection{Statistics}

The experiment was carried out in a randomized complete block design. Collected data were analysed by one-way ANOVA, using GLM univariate procedure, to assess significant $(P \leq 0.05,0.01$ and 0.001$)$ differences among treatments. Mean values were then separated by LSD multiple-range test $(P=0.05)$. Statistics and graphics were supported by the programs Costat (version 6.451) and Excel (Office 2010).

\section{Results}

\subsection{Plant growth}

The test showed a significant improvement in agronomic parameters analysed in tomato plants treated with granular chabazite (3-6 mm) enriched with microorganisms and an improvement in protection against Phytophthora infestans and Leivellula taurica with the use of micronized zeolite also enriched with microorganisms. 
In particular, all plants treated with micronized chabazite enriched with microorganisms showed a significant increase in plant height, number of leaf nodes, leaf area index, dry biomass, fresh weight and total number of fruits.

In Lycopersicon esculentum L. (Table 1), treatment with chabazite enriched with microorganisms significantly improved plant height $70,141.80 \mathrm{~cm}$ (ZEOB), 138.42 (ZE) compared to $132.34 \mathrm{~cm}$ of the untreated control (Figure 2). It also significantly increased the number of nodes70 per plant, 33.20 (ZEOB), 27.40 (ZE) and 24.70 (CT). There was also a significant increase in LAI Tot, in (ZEOB) and (ZE) with 4.60 and $4.20 \mathrm{~m}^{2} \mathrm{~m}^{-2}$ compared to control with $2.80 \mathrm{~m}^{2} \mathrm{~m}^{-2}$.

The test also showed a significant increase in total biomass (DW Tot) in (ZEOB) with $446.98 \mathrm{~g} \mathrm{~m}^{-2}$, compared to 438,64 $\mathrm{g} \mathrm{m}^{-2}$ of (ZE) and $428.68 \mathrm{~g} \mathrm{~m}^{-2}$ of control (Figure 3). Also with regard to the fruit fresh weight (FW), there was a significant increase in (ZEOB) with $10.30 \mathrm{~kg} \mathrm{~m}^{-2}$, compared to the thesis with only chabazite (ZE), $9.35 \mathrm{~kg} \mathrm{~m} \mathrm{~m}^{-2}$ and the untreated control $8.73 \mathrm{~kg} \mathrm{~m}^{-2}$. The experiment also shows a significant increase in the fruits number (FN), in the thesis with chabazite enriched with microorganisms (ZEOB) with 77.63, compared to 70.20 of (ZE) and 64.20 of the control.

The use of micronized zeolite (D 10) enriched with microorganisms used as a protective treatment for the protection of tomato leaves and fruits has resulted (Table 2) in increased protection from Phytophthora infestans, in fact the plants affected by disease were 1.0 (ZEOB), 1.7 (ZE) compared to 2.8 (CT) (Figure 3). And also with regard to Leivellula taurica the same trend is noted, 1.13 plants affected by the disease in (ZEOB), 2.21 in (ZE) and 4.20 in the untreated control (CT).

Table 1 Evaluation of chabazite zeolites on agronomic characters on plants of Lycopersicon esculentum L.

\begin{tabular}{|c|c|c|c|c|c|c|}
\hline Groups & $\begin{array}{c}\text { Plant height70 } \\
\text { (cm/plant) }\end{array}$ & $\begin{array}{c}\text { Plant nodes70 } \\
\text { (n/plant) }\end{array}$ & $\begin{array}{l}\text { LAI Tot } \\
\left(\mathrm{m}^{2} \mathrm{~m}^{-2}\right)\end{array}$ & $\begin{array}{l}\text { DW Tot } \\
\left(\mathrm{g} \mathrm{m}^{-2}\right)\end{array}$ & $\begin{array}{c}\text { FW } \\
\left(\mathrm{Kg} \mathrm{m}^{-2}\right)\end{array}$ & $\begin{array}{l}\text { FN } \\
\left(n^{\circ}\right)\end{array}$ \\
\hline $\mathrm{CT}$ & $132,34^{c}$ & $24,70^{c}$ & $2,80 \mathrm{~b}$ & $428,68^{c}$ & $8,73^{c}$ & $64,20^{c}$ \\
\hline $\mathrm{ZE}$ & $138,42^{b}$ & $27,40 \mathrm{~b}$ & $4,20^{a}$ & $438,64^{b}$ & $9,35^{c}$ & $70,20 \mathrm{~b}$ \\
\hline ZEOB & 141,80 a & $33,20^{a}$ & $4,60^{\text {a }}$ & 446,98 a & 10,30 a & 77,63 a \\
\hline ANOVA & $* * *$ & $* * *$ & $* * *$ & $* * *$ & $* * *$ & $* * *$ \\
\hline
\end{tabular}

One-way ANOVA; n.s. - non significant; *,**** - significant at $\mathrm{P} \leq 0.05,0.01$ and 0.001 , respectively; different letters for the same element indicate significant differences according to Tukey's (HSD) multiple-range test $(\mathrm{P}=0.05)$

Legend: (CT) control; (ZE) chabazite zeolites; (ZEOB) chabazite zeolites enriched with microorganisms; Plant height and number of nodes measured at 70 days after transplanting; (LAI Tot) total plant defoliations; (DW Tot) plant dry weight; (FW) fruits fresh weight; (FN) fruits number

Table 2 Number of Lycopersicon esculentum L. plants affected by Phytophthora infestans and Leivellula taurica after treatment with chabazite zeolites

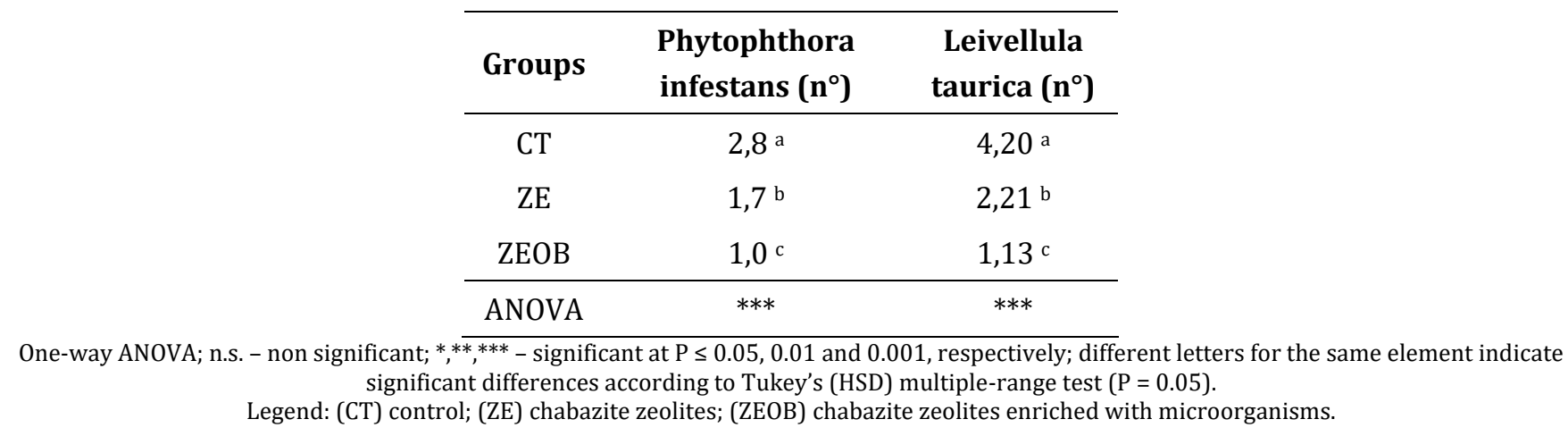



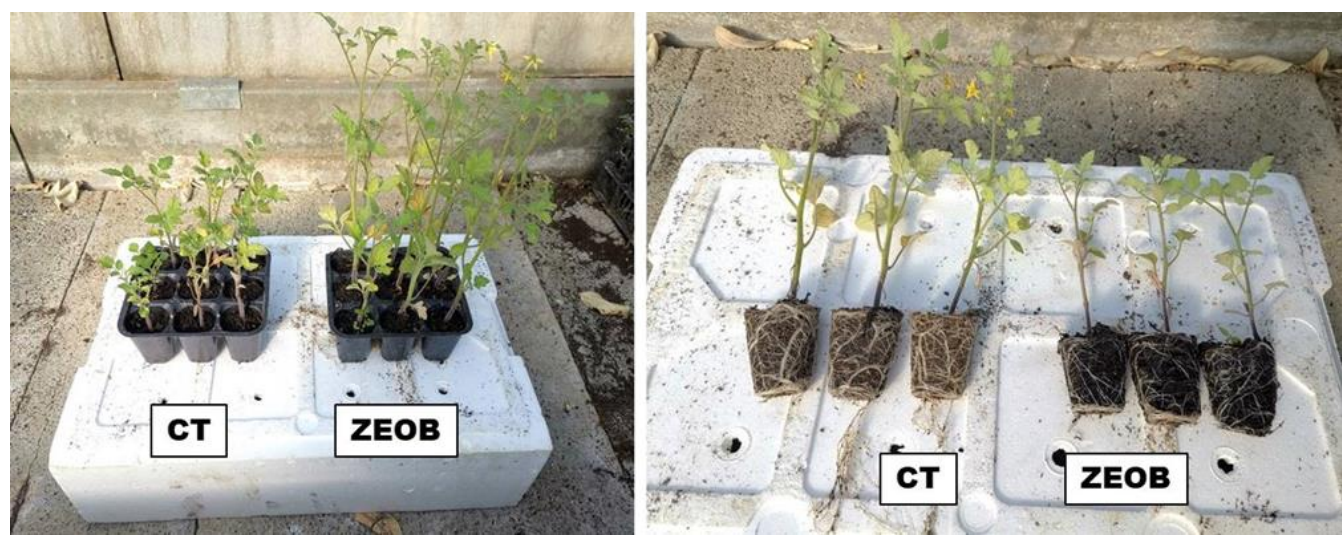

Figure 2 Effect of zeolite enriched with microorganisms on growth (A) and root development (B) in tomato plant nurseries. Legend: (CT) control; (ZEOB) chabazite + microorganisms.
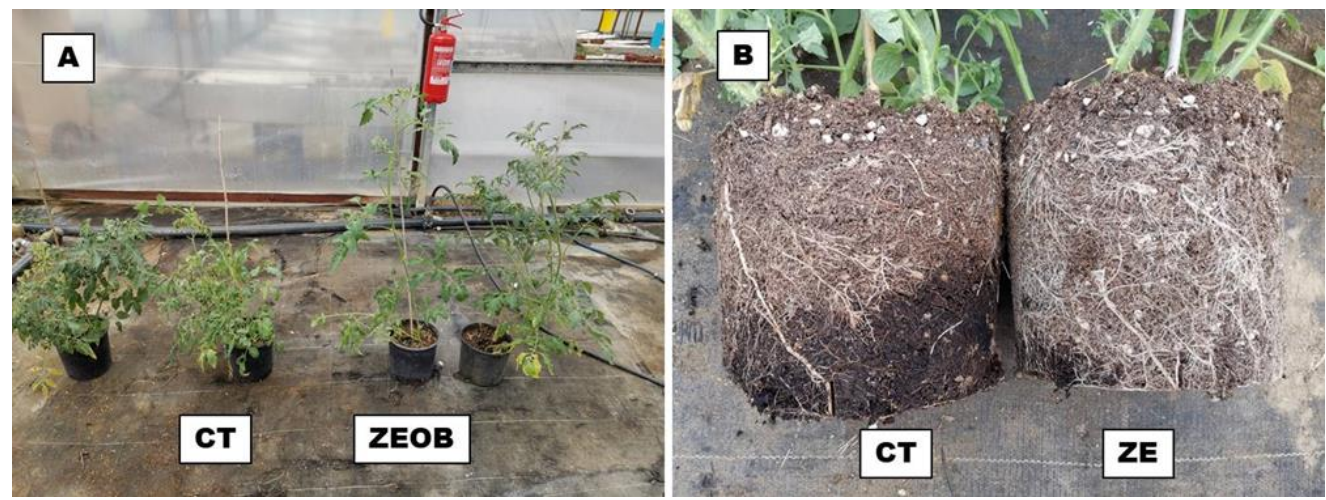

Figure 3 Effect of chabazite enriched with microorganisms on the height (A) and root growth (B) of tomato plants in greenhouses. Legend: (CT) control; (ZE) chabazite; (ZEOB) chabazite + microorganisms
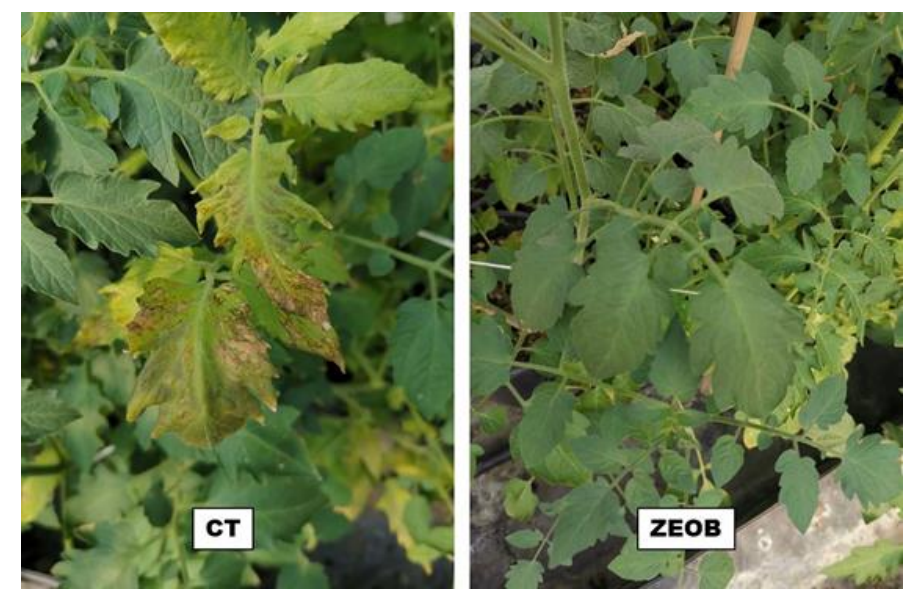

Figure 3 Effect of chabazite enriched with microorganisms on the biological control of Phytophthora infestans. Legend: (CT) control; (ZEOB) chabazite + microorganisms

\section{Discussion}

Zeolites have a high cation exchange capacity, in particular due to the internal cavities of their structure can accommodate calcium, magnesium or sodium ions, and that these ions can be easily replaced by ammonium and potassium ions for which zeolites have a high affinity. 
Zeolites are used in various sectors such as water purification, petrochemical industry, animal breeding and as biostimulants in horticulture, because they are real molecular sieves. In agriculture, the use of granular zeolites $(0-3$ $\mathrm{mm}$ and 3-6 $\mathrm{mm}$ ) introduced in soil or open field cultivation substrates can improve various aspects of cultivation such as seed germination, rooting of cuttings, plant growth for greater efficiency in the use of water, greater resistance to water and salt stress $[13,14]$.

The use instead of micronized zeolites on the plants, guarantees a greater protection of the leaves from sunburn, from the attack of fungi and pathogenic insects (for moisture absorption that reduces the germination of fungal spores, for mechanical problems that cause zeolite dust to insects during flight and breathing, dehydration of insect eggs and during moulting, absorption of ethylene that can act as a vehicle against the fruit by insects that cause damage to crops] [15, 16].

In this experiment it is noted above all that the zeolite-enriched substrates for tomato cultivation determined a significant increase in all the agronomic parameters analyzed (plant height, number of nodes, LAI Tot, total biomass, fresh weight and number of fruits).

In particular, as already confirmed in other experiments, plants grown in chabazite with the addition of rhizobacteria promoting plant growth were significantly better than plants grown in other substrates. The presence of microorganisms in zeolite therefore allows an optimization of fertilizer and water use.

Chabazite zeolite is able to retain water and fertilizer, which reduces leaching into the groundwater and allows optimization of plant use. This is of particular importance when water with high salt concentrations is used (chabazite captures sodium and releases potassium or even in the case of nitrate problems, as zeolite regenerates in the presence of nitrogen) [17]. The interesting aspect found in this study is that the microbial presence improves the cation exchange characteristics of zeolite. The bacteria probably accelerate the passage of nutrients captured by zeolite to the plant through acidification of the substrate, which solubilises the minerals and makes them more available to the plant. This mechanism can occur naturally over a long period of time in the substrate and in the field with indigenous microorganisms normally present, but it can be accelerated if particularly performing microbial colonies are added to zeolite products.

Zeolites can act as a "home" for microorganisms, as is normally the case in nature with clays. In fact, under water stress conditions, microorganisms take refuge inside the clay particles until the environmental conditions are suitable again to colonize the soil. Zeolites are able to actively interact with the organic components present in the soil or brought with fertilization, and have the ability to make more available the mineral and nutritional components present within their crystal lattice, depending on the needs of the plant [18]. In particular, the direct contact of zeolites with the root surface stimulates the production of mucilaginous substances (mucigel) by carrying out a lubricating action able to favour the absorption by the root of minerals and water. Evidence shows that zeolites, once inserted into growing substrates, can lead to an improvement in the physiological aspects of plants, in particular the net photosynthesis rate and chlorophyll content. A plant that photosynthesizes more has more energy reserves available for different metabolic functions [17].

Micronized zeolites, on the other hand, are particularly suitable for protecting plants and fruits from insect and fungal attack. In particular, zeolite chabazite shows more protective properties than other zeolites due to its rough structure, which can therefore cause more discomfort to the adherence and flight of insects attacking plants [10].

A decisive factor for zeolites is the purity of the mineral used. The determination of the chemical-physical characteristics is in fact of particular importance in order not to run into problems during the cultivation cycle in pots or in open field. The evaluation can only be carried out using the RIETVELD-RIR method [11]. All this is to limit the marketing of products that are not of high quality and to ensure that those who use this type of mineral cannot then encounter phytotoxicity problems on plants under cultivation.

\section{Conclusion}

Research has shown that the use of chabazite enriched with microorganisms added to the growing medium can significantly improve the agronomic quality of tomato plants. The use of micronized chabazite enriched with microorganisms can instead protect plants from attack by fungi and pathogenic insects, particularly on tomatoes from Phytophthora infestans and Leivellula taurica.

Zeolites and more specifically chabazite once added into the growing medium can improve the absorption of water and fertilisers and also increase the quality of cultivated plants. The presence of beneficial microorganisms added to 
chabazite, further improves these aspects and provides the plant with greater protection from biotic and abiotic stress. It is therefore very interesting for the grower to use this kind of mineral enriched with microorganisms, especially in the transplanting phase, during cultivation and when the plants are to be protected against fungal and insect pathogens.

\section{Compliance with ethical standards}

\section{Acknowledgments}

The research is part of the "chabamicro" project funded by the company Balco Greenline of Sassuolo (M0), in line with the project "Micronaturale": innovative techniques with low environmental impact for the cultivation and defense of plants.

\section{Disclosure of conflict of interest}

The author declares no conflict of interest.

\section{References}

[1] Galli E and Passaglia E. (2011). Natural Zeolites In Environmental Engineering. In: H. Holzapfel (Ed.), Zeolites In Chemical Engineering, Verlag Processeng Engineering Gmbh, Vienna, 392-416.

[2] Mumpton FA. (1978). Natural Zeolites-A New Industrial Mineral Commodity. In: IVaturalZeolites: Occurrence, Properties, Use, L. B, Sand and F. A. Mumpton (eds.)

[3] Gottardi GE and Galli E. (1985).Natural zeolites. sprinter-verlag, berlinheidelberg, 409.

[4] Passaglia E, Marchi E and Manfredi F. (1998). Zeoliti arricchite in NH4 nella coltivazione in vaso di gerani (Pelargonium zonale). Flortecnica, novembre, 11-15.

[5] Prisa D. (2018). Italian chabazitic-zeolitite and Effective microorganisms for the qualitative improvement of olive trees. Atti del Convegno di Calci (PI) 2017 Atti Soc. Tosc. Sci. Nat., Mem., Supplemento, 125, 13-17.

[6] Ando H and Mihara C. (1996). The fate of ammonium nitrogen applied to flooded rice as affected by zeolite addition. Soil Science and Plant Nutrition, 42(3), 531-538.

[7] Allen ER. (1991). Supplying nitrogen, phosphorus and potassium to plants through the dissolution and ion exchange using a zeolite based substrate. Ph.D. diss., Texas A\&M Univ, College Station, 114.

[8] Chandler JM. (1981). Estimated losses of crops to weeds. ln'. Harulbooh of Pest Management in Agricultutr (Ed., D. Pimentel), l, 95-109.

[9] Prabhu K, Murugan K, Nareshkumar A, Ramasubramanian N and Bragadeeswaran S. (2011). Larvicidal and repellent potential of Moringa oleifera against malarial vector, Anopheles stephensi (Liston), Insecta: Diptera: Culicidae. Asian Pacific Journal of Tropical Biomedicine, 1(2), 124-129.

[10] Passaglia E and Prisa D. (2018). Contributo delle zeolititi nella mitigazione delle problematiche ambientali conseguenti alle vigenti pratiche agricole. Edizioni lulu, 160.

[11] Gualtieri AF. (2000). Study of NH4+ in the zeolite phillipsite by combined synchrotron powder diffraction and IR spectroscopy. Acta Cryst, B56, 584-593.

[12] Gualtieri AF, Marchi E and Passaglia E. (1999). Zeolite content and cation exchange capacity of zeolite-rich rocks. Studies in Surface Science and Catalysis, 125, 707-713.

[13] Prisa D. (2019). Effect of chabazitic-zeolites and effective microorganisms on growth and chemical composition of Aloe barbadensis Miller and Aloe arborescens Miller. International Journal of Agricultural Research, Sustainability, and Food Sufficiency (IJARSFS), 6(01), 315-321.

[14] Prisa D. (2020). Chabatitic Zeolites With Earthworm Humus Added To The Growing Media To Improve Germination and Growth of Horticultural Plants, International Journal of Scientific Research in Multidisciplinary Studies, 6(5), 24-31.

[15] Prisa D. (2016). Metodi sostenibili e informatica per un'autentica rivoluzione verde. Il floricultore, 53-58.

[16] Prisa D. (2019). Zeolites as additives for the rooting of Camellia japonica and Proteaceae Juss. The International Journal of Engineering and Science (IJES), 8(5), Series I, 10-14. 
[17] Prisa D. (2020). Optimised fertilisation with zeolitites containing Plant Growth Promoting Rhizobacteria (PGPR) in Ranunculus asiaticus. GSC Biological and Pharmaceutical Sciences, 10(1), 096-102.

[18] Prisa D. (2019). Effect of natural zeolites and zeolites added with microorganisms for the growth of cabbage (Brassica oleracea var. capitata L.). World Journal of Advanced Research and Reviews, 4(1), 006-012.

\section{How to cite this article}

Prisa D. (2020). Particle films: chabazitic zeolites with added microorganisms in the protection and growth of tomato plants (Lycopersicon esculentum L.). GSC Advanced Research and Reviews, 4(2), 01-08. 